\title{
Trichlorethylene: A Review
}

\author{
G. F. SMITH \\ From the Medical Branch, H.M. Factory Inspectorate, Bristol 8
}

The physical and chemical characteristics of trichlorethylene are discussed together with its uses in industry and medical practice. Chemical and physical methods of the estimation of trichlorethylene in air have been described, including the use of gas detector tubes, which today is the method most commonly employed.

The metabolism of trichlorethylene was systematically investigated by Butler (1948), who in animals established the identity of the main metabolites appearing in the urine, Powell (1945a, b) having also done this in human subjects. The excretion of these metabolites has since been repeatedly investigated, but the intermediate breakdown products within the body as well as the organ mainly responsible still remain uncertain.

The acute toxicity of trichlorethylene, manifested preponderantly by central nervous system effects, came to be recognized during the second decade of this century, not long after its introduction as a substitute for benzol as a degreasant in Germany during the First World War. The recognition of a possible chronic toxic effect, characterized by a mild psycho-organic syndrome, came much later and is still not universally accepted. Damage to the trigeminal nerve after closed-circuit trichlorethylene anaesthesia was observed soon after its introduction as a general anaesthetic 30 to 40 years ago, and it was shown to be due to breakdown to dichloracetylene in carbon dioxide absorbers. The pure substance seems otherwise not to have a specific effect on this nerve. The balance of opinion, based on human observations and on animal experiments, is against a severe toxic effect on the liver, although individual cases of liver damage in industrial workers have been reported. The sudden fatal collapse of young workers during mild exercise has on rare occasions been described, there being in most cases an element of heavy exposure. Investigations on man and animals indicate that pure trichlorethylene has no severe effect on other systems of the body.

Maximum permissible levels for trichlorethylene in air were reduced from 400 p.p.m. in I947 to 200 p.p.m., and in 196I there was a further reduction to I00 p.p.m., which, except in the Soviet Union, is at present accepted in most parts of the world.

Trichlorethylene, $\mathrm{CHCl}: \mathrm{C}^{-\mathrm{Cl}_{2}}$, has a boiling point of $86^{\circ} \mathrm{C}$., a melting point of $-87.1^{\circ} \mathrm{C}$., and a specific gravity of $\mathrm{I} \cdot 47$ at $15.4^{\circ} \mathrm{C}$. At room temperature it volatilizes readily as its vapour pressure is high and its latent heat low. Its vapour is heavier than air, and it smells like chloroform.

\section{Chemical Characteristics}

One great advantage in industry is its lack of flammability, since trichlorethylene forms combustible or explosive mixtures with air only at high temperatures $\left(4 \mathrm{I}^{\circ} \mathrm{C}\right.$.), but it will become flammable in oxygen-enriched atmospheres at lower temperatures (Jones and Scott, 1943). Thermo-decomposition may readily occur at $120^{\circ} \mathrm{C}$., or even lower,

Received for publication March 17, 1966. especially in the presence of catalysts, such as finely divided aluminium, or on exposure to ultra-violet light; the second of these is preventable by storage in the dark, in dark-coloured bottles, or in cans. Hot flames or glowing surfaces may cause breakdown to phosgene (Ministry of Labour Booklet No. 8) but, in the presence of catalysing metals or when under pressure, more complicated products such as dichloracetyl chloride or hexachlorbenzene may be produced (Stüber, 193I). A more usual product is hydrochloric acid, acid-accepting stabilizers such as triethylamine, ethylenediamine hydrate, thymol, benzylamine, and even petrol and ammonia having been used to prevent its formation. Trichlorethylene does not react with cold inorganic acids but decomposes violently in hot nitric acid. It reacts more readily with alkali, explosive chloracetylenes being formed. Humphrey and McClel- 
land (1944) showed that at $37^{\circ} \mathrm{C}$. trichlorethylene decomposes readily in carbon dioxide-absorbing canisters containing soda lime, with the production of dichloracetylene, which oxidizes readily to phosgene and carbon monoxide. Although trichlorethylene is poorly soluble in water, it is freely miscible in a wide range of other solvents and dissolves gums, plastics, and a wide variety of fats and oils.

\section{Industrial Significance}

Manufacture Trichlorethylene is produced by the chlorination of acetylene and is separated from the tetrachlorethane, also produced, by fractionation (Riegel, 1949). It has many synonyms such as Alyglen, Blacosolve (U.S.A.), Cecolene, Cecosolve (U.S.A.), Chlorylen (Germany), Crawshawpol (paints), Dukeron (paints), Fleckflip, Lanadin (wool cleaning), Lithurin, Perm-a-chlor, Petzinol (galvanizing), Trethylene, Triclene, Triklone (U.K., trichlorethylene-soaps), Vitran, and Westrosol, etc. Current British Standards specifications and United States patents lay down permissible standards of purity for various technical grades based on specific gravity, distillation temperature, alkalinity, moisture content, and freedom from contaminants.

Uses in Industry Its versatility, relative chemical stability, non-flammability, volatility, and poor solubility in water make trichlorethylene a very useful solvent. Spain (1965) estimated that there are at least 50 applications in which it may cause hazard. The commonest of these is degreasing, for which it was first used in Germany as a substitute during the First World War (Weitbrecht, 1965). It has found particular use for metal degreasing as a preliminary to plating, anodizing, and painting, having replaced the inflammable benzol formerly used. The commonest type of degreasing tank is an open vat, fitted with condensing coils to prevent the escape of fumes and more recently with lip extraction to limit 'drag-out': less frequently, fully enclosed and automatic degreasers for standardized processes are used, and the use of cold solvent for bench degreasing is not uncommon. It has many other uses, some already superseded, namely as a refrigerant, as a vehicle in silicone parting agents in shell moulding (Tubich, Davis, and Bloomfield, 1960), printing inks, paints, lacquers, varnishes, gas and tar purification, as a vehicle for adhesives, and for drugs, chemicals, and perfume manufacture. 'It is being replaced in dry cleaning and in solvent soaps by perchlorethylene (Combey, 1965). As it takes up substances of high molecular weight without reacting with them, it is useful for fat extraction, wax extraction from cotton, and for impregnation. Its bactericidal properties have been used in egg preservation, insecticides, and hair-washes. Since it has a stable viscosity, it has been used in low temperature research (Imperial Chemical Industries).

\section{Medical Uses}

Trichlorethylene is supplied for medical purposes under the name Trilene (or Trimar) in Great Britain and Trethylene in the United States of America. The standards of purity laid down in the British Pharmacopoeia (1963) allow $0.01 \%$ by weight of thymol preservative and not more than $0.001 \%$ of a blue dye, used to distinguish it from chloroform; it must be free from chloride, free chlorine, phosgene, acid, and non-volatile matter.

Anaesthesia Usually given in combination with gas and oxygen, this is its main surviving use in medicine. It was introduced into Great Britain about 30 years ago, as a general anaesthetic, following recommendations made by Hewer (1942, 1943) and Hewer and Belfrage (1938) about ro years after its introduction into the U.S.A. Although it has been said to have many of the characteristics of an ideal anaesthetic by Striker, Goldblatt, Warm, and Jackson (1935) and Wagner (1946), it has a limited working range, good muscular relaxation being difficult to achieve. Its non-flammability enables it to be used with an electrical cautery (Hunter, 1964). The very low incidence of adverse effects on the vital organs reported by Ostlere (1948), in a review of 40,000 cases, underlined its low toxicity compared with chloroform, said to produce a similar type of anaesthesia (Hewer, 1942; Johnson, 1945). The use of trichlorethylene in closed-circuit apparatus was abandoned in 1944 after the danger of dichloracetylene formation had been recognized (Lancet, 1944a; Morton, 1943; Hunter, 1944).

Analgesia It is commonly used as an analgesic in obstetric practice as a $0.5 \%$ mixture with air, as recommended by the Medical Research Council in I954 (British Pharmaceutical Codex, 1963; Extra Pharmacopoeia, 1958). Following reports of anaesthesia in the distribution of the sensory root of the trigeminal nerve in trichlorethylene workers, the use of trichlorethylene inhalations as an analgesic for trigeminal neuralgia was introduced by Plessner (I9I6a, b). Later experience and experimental work showed, however, that this treatment was nonspecific and largely ineffective (Oljenick, 1928; Krantz, Carr, Musser, and Harne, 1935; Rubinstein Painter, and Harne, 1939). Trichlorethylene has 
been used for angina pectoris, crushable ampoules for inhalation being listed in the British Pharmaceutical Codex (1963). Ellis and Bryce Smith (1965) have successfully used trichlorethylene inhalations to relieve the pain of post-operative breathing exercises.

Its use as an abreaction reagent in psychoanalysis was described by O'Connor (1954). Trumper, Thelwall Jones, and Taylor (I936) reported on its superiority over ether and spirit as a wound cleanser. Its earlier use as an anthelminthic was mentioned by Lande, Dervillée, and Nun (1939).

\section{Determination of Trichlorethylene in Air}

Chemical Methods Formerly trichlorethylene was commonly determined by estimation of the chloride released by either combustion or hydrolysis (Tebbens, 1937; Elkins, Hobby, and Fuller, 1937; Alford, 1947; and Pernell, 1944). For indirect methods, absorption media such as amyl acetate, alcohol or silica gel have been proved efficient (Elkins et al., 1937; Goldman and Seegmiller, 1943; Forssman and Holmquist, 1953), but direct combustion methods, described by Tebbens (1937) and Dudley (I94I) for field surveys, have been equally useful. Buchwald (1965) stated that gas detector tubes developed over the last 20 years (Gisclard, 1960; Dräger and Dräger, 1957) could not be accurate to more than $\pm 20 \%$, an objection met by Kitigawa (I96r) by means of a special calibration method. The discovery of the pyridine reaction by Fujiwara in 1914 (von Oettingen, 1937, 1964) and independently by Ross (1923) laid the foundation for this commonly used method, which replaced less reliable colorimetric tests (Cole, 1926). Trichlorethylene, when heated with pyridine and alkali, forms a glutaconaldehyde of a characteristic colour, the intensity of which is proportional to the test concentration; Webb, Kay, and Nichol (1945) and Brüning and Schnetka (1933) found that substances, such as chloroform, with three chlorine atoms attached to one carbon in the molecule react the most sensitively. Measurement is mostly spectrophotometric at the optimum wavelength of $430 \mathrm{~m} \mu$. Earlier workers relied solely on direct visual comparison either with known solutions or with fuchsinin-water standards prepared beforehand (Webb et al., 1945; Barrett, 1936; Brüning and Schnetka, 1933; McCollum, 1930).

The use of multiple units for fluid absorption media was found by Elkins and his colleagues (I937) not to produce the calculated $20 \%$ increase in efficiency. With suitably designed single or double units, collection rates of 70 to $80 \%$ have been obtained (Elkins et al., 1937; Barrett, 1936). Similar efficiencies have been provided by silica gel absorbers (Forssman and Holmquist, 1953; Hickish, Smith, and Bedford, I956; Fahy, 1948). For concentrations of 90 to 340 parts of trichlorethylene per million of air, a rate of flow through the absorption apparatus of one to two litres per minute was found by Pernell (1944) and by Webb and his colleagues (I945) to achieve collection rates of about $90 \%$.

Physical Methods With the exception of halide detector lamps (Ministry of Labour, S.H. and W., Booklet No. 8), physical methods are accurate, although complicated and requiring expensive apparatus. Gas interferometers and ionization detectors, used often in conjunction with gas chromatographs, can be used for trichlorethylene, some instruments providing continuous analysis (Giever and Cook, 1960; Harrold and Gordon, 1939; Keenan, 1960; Talvitie, 1958; Patty, 1939; Andreatch, 1962). Applicable methods based on the direct measurement of vapour partial pressures have also been described (Kay, Reece, and Drinker, 1939; Couchman and Schulze, 1939; Silverman, Reece, and Drinker, 1939). Hunter (1949) devised an ingenious and simple method, relying on the displacement by trichlorethylene vapour of a known volume of air. Morgan and Duxbury (1965) described a method of radioactivation analysis, in which ${ }^{38} \mathrm{Cl}$ produced by irradiating trichlorethylene samples was measured. The expected error of gas interferometers may be as low as 0.01 (Patty, 1939), and an accuracy of about 0.01 to 0.02 can be obtained with ionization detector instruments. Morgan and Duxbury (1965) did not detail the accuracy of activation analysis but they found that the minimal detectable amount of chlorine was I mg. Accuracies of $98 \%$ were obtained with vapour pressure instruments by Kay et al. (1939) and Couchman and Schulze (1939).

\section{Metabolism}

Absorption The lungs are by far the most important route, absorption through the skin being generally regarded as negligible (Malkinson, I960; Lande et al., 1939); McCord (1932) and Gonin and Fraisse (1947), however, thought that transcutaneous absorption was possible. Human experiments have shown 50 to $60 \%$ retention of trichlorethylene (Teisinger, 196I; Bardodej and Vyskocil, 1956; Soucek and Vlachovà, I960; Bartonicek, I962; Ahlmark and Forssman, 1951a, b) but retention calculated from industrial exposures, namely by Grandjean, Münchinger, Turrian, Haas, Knoepfel, and Rosenmund (1955), was $70 \%$.

By equilibration experiments with trichlor- 
ethylene-air mixtures on whole blood, plasma, washed cell suspensions, haemoglobin solutions, and water, Powell (1945b, 1947) concluded that the greater part of trichlorethylene uptake in the blood is by haemoglobin in the erythrocytes. In her earlier investigations, Powell (1945a) showed that arterial blood contained more trichlorethylene than venous blood and that it had largely left the blood four days after exposure. Transplacental passage of trichlorethylene was demonstrated by Helliwell and Hutton (1950). Estimation of trichlorethylene uptake of artificial plasmas, representing only the aqueous and fatty contents, showed that absorption is almost certainly dependent on their protein content and certainly dependent on their fat content. Fabre and Truhaut (1952) suggested, without experimental evidence, that the lipids in the erythrocyte membrane of rats absorbed trichlorethylene. Accumulation of trichlorethylene in fatty tissue in man was suggested by Bartonicek and Teisinger (1962) and Clayton and Parkhouse (1962). Génevois (1936) suggested that in mice the rate of uptake of trichlorethylene in the water content of tissues was probably in direct relationship to the vapour concentration, resulting in the slower absorption of substances of higher molecular weight. The duration of exposure influenced the distribution of trichlorethylene in animal tissues, the lungs containing the most after acute exposures, whereas organs such as the gonads and spleen contained a larger amount after chronic exposures (Brüning and Schnetka, 1933; Fabre and Truhaut, 1952). In dogs, fat was found to be the tissue which retained trichlorethylene the longest (Barrett, Cunningham, and Johnston, 1936).

Metabolic Breakdown Estimates of the amount of trichlorethylene metabolized after absorption made by Teisinger (196I), Soucek and Vlachovà (1960), and Bartonicek (1962) varied in human experiments between 72 and $80 \%$. Trichloracetic acid in the urine after trichlorethylene exposure was demonstrated by Powell (1945a) in human subjects and in dogs by Barrett and Johnston (1939), who also showed the presence of chloroform in these animals. Butler (1948, 1949c) demonstrated trichlorethanol, present as a glucuronide, after the administration of trichlorethylene and chloral hydrate.

Studies using isolated tissue slices, from dogs (Butler, 1949b), have shown that no particular organ is responsible for trichloracetic acid production and, from rats, that the spleen and lungs (Fabre and Truhaut, I952) and not the liver were most active. Precursors during the oxidation to endmetabolites were first postulated by Barrett et al.
(1936), and intermediates, some rather improbable, such as unsymmetrical tetrachlorethane (Barrett and Johnston, 1939), the toxic and unstable trichlorethylene oxide (Powell, I945a), and, more commonly, chloral hydrate (Bardodej and Vyskocil, 1956; Ahlmark and Forssman, 1951a, b), have been suggested, but as yet none of these substances has been demonstrated. Bartonicek and Teisinger (1962) have shown that trichloracetic acid and trichlorethanol are probably formed separately from chloral. Monochloracetic acid together with hydrochloric acid may arise directly by splitting of the double bond of the trichlorethylene molecule (Bardodej and Vyskocil, 1956). From controlled exposures in man, it has been shown that between 19 and $31 \%$ of absorbed trichlorethylene appears as trichloracetic acid, and the ratio of trichloracetic acid in milligrams per litre of urine to trichlorethylene in parts per million of air varies between $2: I$ and $I: I$ (Teisinger, 196I; Soucek and Vlachovà, 1960; Bartonicek, 1962) according to the degree of exposure. Industrial exposures have yielded lower values, namely 5 to $13 \%$ of trichloracetic acid with ratios of trichloracetic to trichlorethylene varying between I.6:I and 3:I (Rivoire, Génevois, and Tolot, 1962; Friberg, Kylin, and Nyström, I953; Frant and Westendorp, 1950; Elkins, 1961). Grandjean and his colleagues (1955) stated that good correlation between the two values could be obtained in trichlorethylene workers only if the exposure rate were used rather than trichlorethylene concentrations, and they quoted a 3 to I relationship. The output of trichloracetic acid and trichlorethanol in faeces, sweat, and saliva was too small to influence these values (Bartonicek, I962).

In man and animals, the greater proportion of the trichlorethylene retained appears as trichlorethanol. Estimates of 35 to $45 \%$ were obtained in human experimental exposures (Teisinger, I96I ; Soucek and Vlachovà, I960; Bartonicek, I962) and of 22 to $45 \%$ in laboratory animals (Lob, 1960; Bartonicek and Soucek, 1959). Teisinger (196I) found that monochloracetic acid accounted in man for $30 \%$ of the trichlorethylene retained, whilst Soucek and Vlachovà (I960) put this at $4 \mathrm{I} \%$.

Distribution of Metabolites within the Organism Since plasma contained 4.8 times less trichloracetic acid than red cells, from which it could be removed only by elution, Bartonicek (1962) concluded that erythrocytes selectively absorb this metabolite. A similar selectivity was found in rats by Fabre and Truhaut (1951, 1952), but Bartonicek and Soucek (1959) considered that, in rabbits, trichloracetic acid was more firmly bound to serum albumins. Paykoc and Powell (1945) demonstrated 
that, when injected, trichloracetic acid was excreted at the same rate as if formed by the metabolism of trichlorethylene, since it diffused rapidly into extracellular fluid where it remained. The opposing view that metabolites traverse cells seemed to be supported by the demonstration by Bartonicek (1962) of their excretion in saliva, sweat, and faeces. The unchanged excretion rate of trichloracetic acid after injection indicated, to Soucek and Vlachovà (1960), its fixation on to protein in the erythrocytes and plasma. Fabre and Truhaut (1952) found that, after acute exposures, the largest amount of trichloracetic acid was found in the spleen, whereas after chronic exposures the largest amount was in the lungs. After trichlorethylene anaesthesia, Powell (1945a) found that maximal concentrations of trichloracetic acid in blood occurred in about 48 hours, tailing off to low values in seven to 12 days, according to the dose; peak plasma levels of trichlorethanol occurred somewhat earlier, namely, five to 24 hours after inhalation, according to Butler (I949a).

Excretion of Unchanged Trichlorethylene Through the lungs, this was found to start at maximal levels and was complete within 24 to 48 hours (Powell, 1945a; Bartonicek, 1962; Ahlmark and Forssman, I95Ib), but substances which inhibit the metabolism of trichlorethylene, such as disulfiram, increased pulmonary excretion by three times. Urinary excretion has been found to be very slight in man (Powell, 1945a; Teisinger, 1961; Brüning and Schnetka, 1933) and in animals (Fabre and Truhaut, 1952; Forssman and Holmquist, 1953).

Excretion of Metabolites Bartonicek (1962) showed that blood, at its peak level, contains 5.2 times more trichloracetic acid than urine. After single inhalations, it is first excreted within one or two hours (Barrett et al., 1936; Ahlmark and Forssman, I951a, b) or in 12 to 24 hours, as found by Powell (1945a). Maximum urinary levels usually occur after 48 hours (Powell, I945a; Soucek and Vlachovà, 1960; Ahlmark and Forssman, I95 Ia; Bartonicek and Soucek, 1959). Rather earlier peaks were found by Barrett and his colleagues (1936), and after trichloracetic acid by mouth, as reported by Ahlmark and Forssman (I95Ia). Peaks tended to occur later after trichlorethylene ingestion, as found by Bardodej and Vyskocil (1956), and after the gassings reported by Mikiskova and Mikiska (1960) and by Friberg and his colleagues (1953). In animals, maximal levels appeared within two to three days (Bartonicek and Soucek, 1959; Barrett et al., 1936; Friberg et al., I953; Ahlmark and Forssman, I95 Ia). The overall rate of decline to minimal urinary levels was regarded by Soucek and Vlachovà (1960) as the sum of two exponential rates, with half-periods of excretion of 50 to 70 hours. The total period of excretion was between 10 and 14 days, as found by Soucek and Vlachovà (1960), Bartonicek (1962), Ahlmark and Forssman (I95Ia), and Powell (I945a), the latter having stated that changes in blood and urine trichloracetic acid levels follow a roughly parallel course. Prolonged excretion rates were recorded after leaving industrial exposure by Rivoire and his colleages (1962). Trichlorethanol is excreted through the lungs in man for about four days after exposure (Bartonicek, 1962), and it appears as a glucuronide in the urine (Butler, 1949c) within one to two hours, reaching maximum levels, roughly twice those of trichloracetic acid, in 24 hours, after which there is an exponential decline to the lowest levels in 12 to 14 days (Bartonicek and Soucek, 1959; Butler, I949a; Bartonicek, I962; Mikiskova and Mikiska, 1960; Soucek and Vlachovà, 1960). The half-period of excretion of the two rates was found by Soucek and Vlachovà (1960) to be 24 and 40 hours. Monochloracetic acid appears in the urine a few minutes after the beginning of exposure, reaches maximal levels in four to five hours, and falls to the minima exponentially in about four days (Soucek and Vlachovà, 1960), there being only one excretion phase with a half-period of about 15 hours. The relationship between trichloracetic acid and trichlorethanol in human and animal urine was found to vary between $I: 2 \cdot 4$ and $I: 3$, but since the two have different rates of excretion, the time of sampling after exposure will materially influence the result (Bartonicek, 1962; Soucek and Vlachovà, 1960; Bartonicek and Soucek, 1959).

Determination of Trichlorethylene and Metabolites in Biological Media The collection of expired air for trichlorethylene estimation necessitates collection apparatus designed to avoid resistance to expiration (Powell, I945a; Bartonicek, 1962; Bartonicek and Teisinger, 1962). Forssman and Holmquist (1953), using rats, estimated residual trichlorethylene in the exposure chamber after making a correction for absorption by fur. Trichlorethylene in blood, pulped tissue, or urine has been removed with a current of air by Powell (1945a, 1947), Fabre and Truhaut (I95I, 1952), and Kulkarni (1944) or with steam distillation by Brüning and Schnetka (1933), Barrett et al. (1936), and Habgood and Powell (1945). In all cases, estimation was done by the pyridine reaction. Brain and Helliwell (1949), who followed Rogers and Kay (1947), developed a more sensitive single-phase pyridine reaction for the estimation of trichlorethylene in blood samples. Trichloracetic acid is 
separated from protein in blood and tissues by precipitation with sodium tungstate. The supernatant fluid is filtered off and its trichloracetic acid content is estimated by the pyridine reaction, which has replaced earlier colorimetric methods described by Levine and Bien (1934); this reaction is used also for the determination of trichloracetic acid in faeces, sweat, saliva, and urine (Soucek and Vlachovà, 1960; Bartonicek, 1962; Ahlmark and Forssman, 1949; Forssman and Ahlmark, 1946; Powell, 1945a; Fabre and Truhaut, 1952; Butler, 1948). Trichlorethanol glucuronide in urine is first hydrolysed with acid and then oxidized to trichloracetic acid, as which it is estimated (Soucek and Vlachovà, I960; Butler, I949a; Weitbrecht, 1965). From plasma, the glucuronide must first be extracted with heptane (Butler, 1948) before being estimated in the same way. Soucek and Vlachovà (1960) estimated monochloracetic acid in urine by a paper chromatographic method.

\section{Toxicity of Trichlorethylene and Metabolites}

Acute Toxicity The opinion expressed by Ullmann in 1914 (Calvet, Planques, Ribet, and Coll, 1959) that trichlorethylene is non-toxic has long since been abandoned in view of increasing evidence to the contrary. The contributory role played by breakdown products, particularly in most industrial gassings and closed-circuit anaesthesias, may have confused the issue in some cases. Trichlorethylene and similar substances have been thought to have an effect on cell metabolism at the water-fat interphase, particularly relevant in the case of nervous tissue; to a degree proportional both to its coefficient of distribution between water and fat and to its vapour pressure (Génevois, 1936). Slight metabolic changes occur in about $20 \%$ of anaesthesias with trichlorethylene (Hewer, 1942; Ostlere, 1948). Using such criteria as narcosis, body weight changes, and tissue histology, Carpenter, Smyth, and Pozzani (1949) and Adams, Spencer, Rowe, McCollister, and Irish (I95I) found that the acute vapour toxicity of trichlorethylene was low in animals, being about half that of carbon tetrachloride and the same as that of toluene. Génevois (1936) demonstrated increasing toxicity with increasing chlorination of the ethylenic hydrocarbons. This was not, however, found by Joachimoglu (1921), who used fish swimming in aqueous solutions of these solvents. Most workers have found that perchlorethylene is rather more toxic than trichlorethylene. Death in acute overwhelming exposures is most commonly due to respiratory and cardiac failure, although there is a wide difference between the minimum narcotic and fatal doses. Less frequent causes of death have been pulmonary oedema due to inhalation of phosgene, produced as a thermal breakdown product of trichlorethylene vapour (Spolyar, Harger, Keppler, and Bumsted, I95I), and liver failure where contaminants or unassociated medical conditions may contribute.

Chronic Toxicity This has been thought to be non-existent, rare, or doubtful (Lloyd Potter, 1958; Johnstone, I94I ; Ministry of National Health and Welfare, Canada, 1949), but there is increasing opinion that chronic toxicity may be more important than acute (Lachnit and Rankl, 1950; Moeschlin, quoted by Browning (1965); Borbély, quoted by Merewether (1956)), the nervous system again being particularly affected. Women are said to be more susceptible than men. Rare cases of sudden death shortly after leaving work, thought to be due to heart failure, have been described. Bartonicek (1960) found negligible changes in rabbits exposed to trichlorethylene over long periods.

Acute Exposures and the Central Nervous System The cardinal symptom of gassing is unconsciousness, carbon dioxide excess and oxygen lack in confined spaces probably contributing in some cases (Hamilton and Johnstone, 1945; Merewether, 1956; Longley and Jones, 1963). Prenarcosis characterized by mild excitatory symptoms has been described in industrial over-exposures by Lob (1960), Carrieu and Marc (1926), and by Barrett and his colleagues (1936). Bardodej and Vyskocil (I956) stated that narcosis proceeds in two stages, the duration of which is related to the degree of exposure. After recovery, contaminants may contribute to such manifestations as prolonged headache, as described by Cotter (1950) and Chalupa, Synkova, and Secevik (1960), or cerebral irritation, resembling that of encephalitis with hallucinations as described by Cotter (1950) and the Chief Inspector of Factories (1939). Alterations in the electroencephalograph have been described by Desoille, Pinchon, Lille, and Bourguignon (1962b) and Chalupa and his colleagues (1960), who found that they lasted longer after solvent than after carbon monoxide poisonings and were often accompanied by characteristic changes in the various components of memory. Organic damage to the cerebrum and cerebellum have been described by Bardodej and Vyskocil (1956) as the results of gassing. In animals receiving pure trichlorethylene, Adams et al. (I95I) reported that the only important acute effect was narcosis, from which recovery without sequel was the rule, and before that there occurred a prenarcotic phase, similar to that in man. Desoille, Pinchon, Jans, and Bourguignon (1962a) found that trichlor- 
ethylene caused electro-encephalographic changes in rabbits similar to those of epilepsy, which could be increased by prolonged alcohol dosage before exposure. Potentiation of the effects of trichlorethylene by small doses of carbon monoxide was demonstrated by Forssman, Gernandt, and Goldberg (1948), even after elimination of carboxy haemoglobin from the blood. Grandjean (1960) demonstrated the suppression of inhibition responses in rats after single exposures at concentrations down to 200 p.p.m. The effects of drinking trichlorethylene do not differ materially from those of gassing; unconsciousness may come on more quickly and it may last longer, even up to three days, periods up to 36 hours, however, being more usual (Stentiford and Logan, 1956; Todd, 1954; Teare, 1948; Calvet et al., 1959). Delay in onset of narcosis may occur due to a full stomach (Naish, 1945), or alcohol may potentiate the effects (Chief Inspector of Factories, 1953), but in the case described by Stephens (1945) habitual taking of alcohol was thought to have caused resistance. Excitatory phenomena after drinking trichlorethylene, possibly contributed to by contaminants, have been described by Matruchot (1944-1945), Todd (1954), and Calvet and his colleagues (1959).

Excitement during the first and second stages of trichlorethylene anaesthesia has been reported (Hewer and Hadfield, I94I; Hewer, 1942, I943; Striker et al., 1935). Many causes for convulsions under trichlorethylene have been suggested, as by Pask (1942). Under closed-circuit anaesthesia, dichloracetylene formation has been postulated as a possible factor by Garland (1942) and Condon (1948), although they have been described only in association with respiratory arrest by A. R. Hunter (1944) and Bernstine (1954). Surgical stimulation under light anaesthesia appeared to have been the cause in the case, described by Culbert (1942), that received open trichlorethylene. Therapeutic inhalations of pure trichlorethylene produced abnormalities of the electro-encephalogram in the case of Geiger (1943). In animals receiving pure trichlorethylene, Desoille et al. (1962a) and Carrieu (1927) thought that convulsions were an anoxic effect. Post-anaesthetic headache is usually transitory and infrequent (Hewer and Hadfield, 194I), the severe case of McAuley (1943) probably having been due to dichloracetylene. In rare instances, confusional states have been caused by the potentiation of trichlorethylene by hexabarbitone, used for induction (D. Hunter, 1944). Dichloracetylene was probably the cause of the brain damage described in the case of Humphrey and McClelland (1944) and in that described in the Lancet (1944a).
Chronic Exposure and the Central Nervous System Some of the symptoms attributed to acute poisoning feature also in chronic poisoning. Grandjean et al. (1955) found a significant incidence of fatigue, headache, loss of memory, intolerance to alcohol and tobacco, and of depression, in order of frequency, among degreasers; although they regarded these as typical, they could find no correlation between the frequency of subjective complaints and the degree of exposure. Frant and Westendorf (1950) attributed this difficulty to the habituation effect of long exposures. Weitbrecht (1965) and Bardodej and Vyskocil (1956) did find such a correlation for lengths of exposure of over Io years. Objections to reliance on subjective complaint were partly met by Ahlmark and Forssman (I95Ib), who accepted only severe and typical complaints, associated with a high urinary trichloracetic acid output. The testing of memory, intellect, and concentration of degreasers enabled Grandjean and his colleagues (I955) to demonstrate a mild psycho-organic syndrome characterized by slowing of thought, perseveration of ideas, difficulties of attention, and emotional changes. Bardodej and Vyskocil (1956) found a similar effect based on tests of attention, and Trense (1965) suggested that such tests might be used for the screening of degreasers for chronic poisoning. No unexposed controls were used by any of the above workers, except that Ahlmark and Forssman (195Ib) made comparison with statistics provided by the Swedish Occupational Hygiene and Health Department. Most workers have found a correlation between symptoms and the urinary trichloracetic acid level, but observations by Frant and Westendorf (1950) and reports by the Chief Inspector of Factories (1959, I960) demonstrated no such relationship, and Bardodej and Vyskocil (1956) thought that urinary trichloracetic acid was a poor index of chronic intoxication. Behaviour changes in rats after prolonged exposures to pure trichlorethylene were investigated by Bättig and Grandjean (1963). They found depression of neuromuscular activity and reduction of fear inhibition. Trichlorethylene has an addiction risk, Stüber (I93I) having found 12 cases among 284 intoxications. A background of mental instability largely accounted for the hypomanic changes sometimes seen in such cases (O’Connor, 1954).

Headache has been considered to be the earliest sign of chronic intoxication by McCord (1932), Baader (1927), and Wurm (I93I). Vertigo has been reported to be characteristic by Kleinfeld and Tabershaw (1954) and by the Chief Inspector of Factories (1952, 1960); O'Connor (1954) and Hewer and Hadfield (I94I) thought that impurities were 
likely to be the cause. Tiredness and sleepiness come on typically at night after leaving work (Hickish et al., 1956; Isenschmid and Kunz, I935b), but they may be alternated with insomnia at weekends, as mentioned by Lachnit and Rankl (1950). These two symptoms have been generally accepted to account for suppression of libido. Bardodej and Vyskocil (1956) found insignificant changes in 17-ketosteroid output, and Lachnit and Rankl (1950) found none. Intolerance to alcohol, typified by flushing of the face and dizziness after small quantities, was described by Lachnit and Rankl (1950), Grandjean and his colleagues (1955), and Bardodej and Vyskocil (1956).

Effects on Peripheral Nerves The neuritis described by Stüber (I93I) in German industrial workers is now thought to have been due to impurities. Many recent surveys in industry have indicated possible damage to both spinal and autonomic nerves, similar effects having been produced in animals exposed to pure trichlorethylene by Adams and his colleagues (I95I).

Of the 284 cases reviewed by Stüber (I93I), there were nine of visual disturbances, including retrobulbar neuritis, possibly also present in the cases described by Isenschmid and Kunz (I935a, b), Plessner (I9I6a), Baader (1927), and the Chief Inspector of Factories (1952). Slight swelling of the optic disc has been thought typical by Oljenick (1928) and Kramer (I92I) in cases receiving therapeutic inhalations, and by Jackson (1934) in anaesthesia cases. None of the surveys on industrial workers revealed this condition.

Anaesthesia of the sensory endings of the trigeminal nerve in trichlorethylene workers has been described by Stüber (193I), Bardodej and Vyskocil (1956), Baader (1927), and Plessner (1916a). Treatment early this century of trigeminal neuralgia by pure trichlorethylene inhalations appeared to achieve a high success rate (Plessner, 1916a; Seelert, 1922; Hildesheimer, I92 I; Rubinstein, I937), but most later reports were less encouraging, particularly in chronic cases (Kramer, I92I ; Blumenthal, I924; Glaser, 1931). The experimental evidence of Blumenthal (1924), the observations during anaesthesia by Jackson (1934) and Hewer (1942, 1943), and by Oljenick (1927) during treatment by inhalation indicated no specific effect on this nerve. The results of faradic stimulation of the fifth nerve of dogs given trichlorethylene by Rubinstein et al. (1939) supported the view that pain was relieved by general analgesia or sedation. The two cases of permanent relief of trigeminal neuralgia described by Eichert (1936) could not, however, be explained either by contamination or generalized analgesia.
Goldblatt and Goldblatt (1956) stated that anosmia was characteristic of chronic poisoning, and damage to other cranial nerves has been reported by James (1963), Isenschmid and Kunz (1935b), and Plessner (I9I6a). Damage to the fifth nerve by trichlorethylene anaesthesia has been attributed to dichloracetylene (Enderby, I944; Morton, 1943), and Humphrey and McClelland (1944) excluded the possibility of a neurotropic virus as a cause. Elam (I942) found no case among I,000 patients. Effects on other cranial nerves after industrial gassings have been reported by Lachnit and Rankl (1950) and after anaesthesia by Striker and colleagues (I935), Humphrey and McClelland (1944), and Carden (1944). Hill (1966) described exposure to accumulated breakdown products, possibly including trichloracetylene, resulting in fatal paralysis of the muscles of the neck, face, throat, and respiration. In two other milder cases, numbness of the face was a residual symptom.

Chronic Exposure and the Alimentary Tract Anorexia, nausea, vomiting and intolerance to fatty foods have been regarded as chronic gastrointestinal effects in trichlorethylene workers by Rivoire et al. (1962), Ahlmark and Forssman (I95Ib), Stüber (I93I), Challen and Hickish (I963), and Trense (1965). Grandjean and his colleagues (1955) thought that malfunction of the autonomic nervous system was a contributory factor. Bardodej and Vyskocil (1956) found no significant incidence in their subjects.

Severe damage to the liver resulting from industrial exposure is uncommon (Browning, 1952, 1959) and is thought to occur only after heavy exposure, toxic breakdown products possibly contributing (Derrick and Johnson, I943; Willcox, 1934a, b). Acute massive necrosis was found by Joron, Cameron, and Halpenny (1955) and by Priest and Horn (1965), no non-occupational factor having been discovered. Investigation of groups of workers has indicated a disturbance of fat metabolism and a failure of the esterification of cholesterol according to Guyotjeannin and van Steenkiste (1958) and Ollivier (1944-1945), and slight changes in liver function tests have also been described by Lachnit and Rankl (1950) and Trense (1965). Slightly increased levels of serum glutamic oxalacetic acid and aldolase in those exposed at work have been shown by Lachnit and Pietschmann (196I) to occur only if they had received beforehand doses of alcohol just below that amount required to produce a rise in unexposed controls; this seemed to indicate that trichlorethylene is likely to be hepatotoxic only in those who habitually take alcohol. Others undertaking the investigation of trichlorethylene workers 
have found no evidence of liver dysfunction. Seifter (1944) produced hepatic insufficiency associated with slight histological changes in dogs exposed to pure trichlorethylene at intensities resembling industrial exposures, but Adams and his colleagues (195I), Taylor (1936), and Carrieu (1927) produced only congestion of the liver in animals exposed for long periods.

Acute Exposure and the Alimentary Tract Vomiting has been reported after industrial gassings (Cotter, 1950) but after anaesthesia it has mostly been attributed to dichloracetylene (Culbert, I942; McAuley, 1943; Enderby, 1944; Carden, 1944), although Willcox (1934b) thought that, as with chloroform, this may be due to some degree of liver damage. The incidence of post-anaesthetic vomiting, based on the observation of large numbers of administrations is low (Elam, 1942; Griffiths, 1942; Haworth and Duff, 1943; Gordon and Shackleton, 1943). Gastro-intestinal irritation after ingestion, the purity of the trichlorethylene being mostly in doubt, has been said to be severe (Stephens, I945; Calvet et al., 1959), but Matruchot (1944-1945) was unable to confirm this by oesophagoscopy.

Liver damage after acute exposure is rare, and in most cases there is the added possibility of either contaminants or some non-occupational factor having played a part. In the gassing cases with acute yellow atrophy reported by the Chief Inspector of Factories (1930-1950) and by Carrié, Perrault, and Bourdin (I94I), and in those of Cotter (1950) with functional disturbances, the part played by contaminants may have been significant. Similar factors may have been important in the case described by Willcox (1934a, b). It has been suggested that the liver may be more at risk if trichlorethylene is absorbed through the portal system (Lande et al., 1939). Kleinfeld and Tabershaw (1954) found some centrilobular necrosis and Stentiford and Logan (1956) found mild dysfunction in cases of ingestion. After anaesthesia, liver damage, considered rare by most anaesthetists, has been reported by Herdman (1945) after a prolonged closedcircuit anaesthetic undertaken for the plastic repair of an apparently healed septic wound, and by Dodds (1945) after an open administration in a woman with toxaemia of pregnancy. Two cases of fatty degeneration were reported in the Lancet (1944b). Dichloracetylene was found by Humphrey and McClelland (1944) to cause no more than slight hepatic necrosis in animals. Neither contaminants nor pre-existing liver disease accounted for the centrilobular necrosis in a 2-year-old child after a short open administration reported in the Lancet (1944c). Even after trichlorethylene injections, Wirtschafter and Cronyn
(1964) produced in animals peak serum glutamic oxalacetic acid levels only one tenth of those produced by equivalent doses of carbon tetrachloride; there was also some mild parenchymatous degeneration. Glycogen depletion of liver cells was the only change produced by inhalation experiments on dogs and mice by Herzberg (1934) and Hunter (1949). Even after exposures of 6,400 p.p.m. given to mice there was no more than centrilobular fatty infiltration, with no increase in extractable fat or changes in the serum ornithine carbamyl transferase activity as found by Kylin, Reichard, Sümegi, and Yllner (I962). Fiessinger and Laur (1936) and Fiessinger and Loeper (194I) demonstrated in mice similar histological changes, only one animal having advanced to complete granular degeneration after longer exposure. The centrilobular changes, usual with chlorinated hydrocarbons, were shown to be due to a reduction of centrilobular circulation by Glynn and Himsworth (1948).

Effects on the Renal System Reports of renal damage in industrial workers are rare. Investigators who have studied trichlorethylene workers have found no significant incidence. Gutch, Tomhave, and Stevens (1965) reported a case of primary renal damage and failure, confirmed by a needle biopsy, in a trichlorethylene degreaser, the retention of metabolites and possible contaminants due to oliguria having been corrected by intermittent peritoneal dialysis. The chronic animal exposures to pure trichlorethylene of Seifter (1944), Carrieu (1927), Taylor (1936), and Adams and his co-workers (I95I) indicated either minimal or no effects. Lande et al. (1939) produced glomerulonephritis in animals given oral doses over long periods. Renal damage after gassing is rare and normally mild, slight tubular damage being the usual finding (Cotter, 1950; Calvet et al., 1959). Marty, quoted by Calvet and his colleagues (1959), described severe renal damage after ingestion.

Effects on the Haemopoietic System Effects on the haemopoietic system are rare, although Patoir, Marchand, and Ducarne (1943) stated that abnormal findings would be more frequent if blood examinations of workers were undertaken more often. This does not seem to be borne out by the negative findings of most of those who investigated groups of trichlorethylene workers, only Bardodej and Vyskocil (1956) having found a 10\% incidence of polycythaemia, thought to be due to marrow anoxia; a degreaser presenting with this condition was described by Patoir and his colleagues (1943). Slight anaemia in industrial workers has been mentioned by Hickish and his colleagues (1956), 
Dérobert (1944-1945), and Tara (1944-1945). The two cases of aplastic anaemia described by Browning (1943) were thought probably not to be occupational. Chronic exposure in animals seems not to cause blood changes (Seifter, 1944; Carrieu, 1927; Adams et al., 195I).

Effects on the Cardiovascular System Bradycardia and precordial pain have been reported in groups of trichlorethylene workers by Bardodej and Vyskocil (1956), who attributed the bradycardia to increased vagal tone. Similar findings with hypotension have been reported in gassings by Cotter (1950), in cases of ingestion by Carrieu and Marc (1926) and Calvet and his colleagues (1959), and in dogs exposed to pure trichlorethylene by Jackson (1934), the latter attributing this effect to central depression. Sudden death in young, apparently healthy people exposed at work, usually after the end of a shift and during mild exercise, has on rare occasions occurred, as reported in the five cases by the Chief Inspector of Factories (1938, 1939, 1952), in three cases by Kleinfeld and Tabershaw (1954), in one case by Bell (195I), and in an addict by James (1963). A similar case has been reported by Trott (1966) in which exposures of 400 p.p.m. had been found. Superimposed acute over-exposure and the possible action of contaminants cannot always be ruled out, and, in spite of a lack of supporting pathology, these deaths have been thought to be due to syncope possibly associated with increased adrenaline sensitivity (Weitbrecht, 1965). Most cases suffered prolonged overexposure. Foulger (1949) found in young people inhaling small quantities of chlorinated hydrocarbons decreased pulse pressure, indicating a general anoxaemia of the viscera, which could theoretically lead to heart failure if the pulse were accelerated by even gentle exercise. An anaesthetic death due to ventricular fibrillation was described by LloydWilliams and Hewspear (1942), but reaction to adrenaline in a local anaesthetic, although improbable, could not entirely be excluded. Bernstine (1954) reported syncope during analgesia in which there was surgical stimulation. Estimates of the incidence of irregularities of the pulse under anaesthesia have varied between nil and $24 \%$ and have often been thought to be due to dichloracetylene (Culbert, 1942 ; Ayre, 1943; Gordon and Shackleton, 1943; Striker et al., 1935; A. R. Hunter, 1944). Mallach, Marquardt, and Werch (1943) and Love (1937) noticed no fall in blood pressure after experimental and therapeutic inhalations. The coronary arteriosclerosis ascribed to exposure in a degreaser by Gerbis (1936) could equally well be explained as an ageing effect. Slowing of conduction of the cardiac impulse without myocardial damage in animals has been produced by Marquardt, Mallach, and Werch (1943), and Mallach et al. (1943). The slowing effect on isolated heart preparations but lack of effect on canine coronary flow were investigated by Krantz, Carr, and Harne (1934) and Krantz et al. (1935); the lack of effect on isolated blood vessel preparations was investigated by both these teams of workers. Increased conduction time was found in dogs by Waters, Orth, and Gillespie (1943), who also demonstrated abnormalities of rhythm in human subjects.

Effects on the Respiratory System The respiratory tract is especially liable to the effects of contaminants and breakdown products. Those undertaking surveys of trichlorethylene workers found no significant incidence of respiratory troubles but Bardodej and Vyskocil (1956) and the Chief Inspector of Factories (1946, 1952, 1953) found a significant incidence of mild congestive signs. Nasal catarrh was stated by Goldblatt and Goldblatt (1956) to be typical of chronic irritation. Derrick and Johnson (1943) described the sudden death of a dry cleaner just after leaving work and attributed it to pulmonary oedema due to the irritation of breakdown products. The effects of contaminants are more important in acute gassings when they may cause even fatal pulmonary oedema due to phosgene derived from trichlorethylene as in the case of Spolyar et al. (195I). Exposures with a less obvious contaminant factor have caused acute toxic but less severe lower respiratory irritation, as reported by Priest and Horn (1965), McCord (1932), Teare (1948), James (1963), Cotter (1950), Carrieu and Marc (1926), and Kleinfeld and Tabershaw (1954). No more than tachypnoea has been the feature of some poisonings (Stentiford and Logan, 1956), respiratory rate increases having occurred in anaesthesia as reported by Gordon and Shackleton (1943), but otherwise pulmonary complications seem few (Ostlere, 1948; Striker et al., 1935). The decomposition of trichlorethylene to phosgene by burning tobacco is now thought to be unlikely (Brit. f. industr. Med., 1945) and Elkins and Levine (1939) showed experimentally that the breakdown to phosgene by cigarettes and cigars is negligible. Acute and chronic exposure of animals to pure trichlorethylene produced minimal pulmonary effects (Desoille et al., 1962b; Adams et al., 1951; Taylor, 1936; Ahlmark and Forssman, 195Ib) but Lande et al. (1939) produced toxic pneumonitis in rabbits relatively easily.

Effects on the Skin and Eyes Trichlorethylene can act as a primary irritant and as a 
sensitizing agent; in the latter case there are rashes described as either dermatitis, dermatoses, or eczema (Schwartz, Tulipan, and Birmingham, 1957). Stüber (I93I) and Schwartz and Russell (I94I) noted a significant incidence, possibly due partly to contaminants, not found by later investigators of groups of degreasers. It has been suggested by Stüber (I93I) that, due to its volatility, trichlorethylene may cause capillary damage, although this may be in doubt. Chemical burns from contact with the fluid have been reported by Carrieu and Marc (1926), Roche, Génevois, and Marin (1958), and Davenport (195I); Maloof (1949) and McBirney (1954) described cases of burns with concentrated vapour. Blistering with the pure liquid has been produced in animals (McCord, 1932; Lande et al., 1939; Carrieu, 1927). Bardodej and Vyskocil (1956) and Ahlmark and Forssman (195 Ib) considered that conjunctivitis was a feature of overexposure; this was not, however, found by other investigators. Anaesthesia of the cornea due possibly to contact with vapour has been noticed in man by Desoille et al. (1962a) and Hunter (1957) and in animals by Carrieu (1927). Conjunctivitis has been reported by Rivoire et al. (1962), Carrieu and Marc (1926), and Stephens (1945).

Toxicity of Metabolites The toxicity of trichloracetic acid is low, it being only a very mild narcotic (Powell, 1945a). Ahlmark and Forssman (I95Ia), comparing trichlorethylene with chloral hydrate, decided that trichloracetic acid was responsible for very little of the toxic effect of trichlorethylene. Marhold, quoted by Soucek and Vlachovà (1960), and Woodard, Lange, Nelson, and Calvery (194I) showed that its $\mathrm{LD}_{50}$ for rats and mice was well below that of the other metabolites, approximately one tenth of that of trichlorethylene. Mikiskova and Mikjska (1960) found that depression of the central nervous system in rabbits with trichlorethanol was greater than that with trichlorethylene. In a further paper (Mikiskova and Mikiska, 1966), these authors demonstrated that trichlorethanol depressed spinal reflex activity and motor cortex electrical excitability at least five to six times more than trichlorethylene, although there was no qualitative difference in their pharmaceutical effects. Although it resembles tribromoethanol (avertin) chemically, Hewer and Belfrage (1938) and Case (1943) found that trichlorethanol had a more toxic effect on the heart. Mikiskova and Mikiska (1966) showed that trichlorethanol decreased the heart rate in guinea-pigs to a much greater extent than trichlorethylene: they observed a similar amplitude depression of the electro-encephalogram tracings in these animals early in trichlorethylene anaesthesia. Bronchodilatation was demonstrated by Adriani and Rovenstine (1943) on isolated human lung tissue. Marhold (Soucek and Vlachovà, 1960), Woodard et al. (194I) and Morrison (1946) found that monochloracetic acid has a toxicity greater than that of trichloracetic acid but rather less than that of trichlorethanol. The keratolytic effect of trichloracetic acid has been mentioned by McLaughlin (1936) and Prosser White (1934).

Prevention and Treatment of Poisoning Maintenance of apparatus and proper working methods are the most important factors in the prevention of over-exposure (Ministry of Labour S.H. \& W. No. 15; Silverman, 1943; Witheridge and Walworth, 1940). The Chief Inspector of Factories (1920-1965) and Stüber (193I) found that failure to work within the capacity of tanks and entry into them without proper precautions accounted for many gassings. Hargarten, Hetrick, and Fleming (I96I) calculated an approximate frequency rate for accidents among trichlorethylene workers, occurring much as described above, of 0.3 per million exposure hours over a Io-year period. Difficulty in the interpretation of the maximum allowable concentration of trichlorethylene in the air and the maximum biological concentration of trichloracetic acid in the urine may be due to the impracticability of dissociating the effects of acute and chronic exposures. Air concentrations together with urinary metabolite levels are generally thought the best means of monitoring working conditions. Until 1957 in Great Britain, Canada, and the U.S.A., the recommended safe level was 400 p.p.m. in air, after which it was reduced to 200 p.p.m. for a $40-$ to 48 -hour working week. Teisinger (196I) argued that such a level would produce toxic effects if pulmonary ventilation were taken into account. In I96I, the level was reduced to 100 p.p.m., the currently accepted level (Morgan, 1964; American Conference of Governmental Industrial Hygienists, 1959; Council on Occupational Health, 1965; Ministry of Labour S.H. \& W. No. 8; British Chemical Industry Safety Council, 1965) although some states in North America had adopted this level about I946 (Flinn, 1946). The current Soviet level of 6 p.p.m. based on neurological tests (Barnes, I96I), has been considered nearest to the upper limit of $40 \mathrm{mg}$. trichloracetic acid per litre of urine suggested by Elkins (I96I), Grandjean and his colleagues (I955), and Ahlmark and Forssman (195Ib), but Challen and Hickish (1963) stated that $33 \mathrm{mg}$. per litre already indicated over-exposure. In a later paper by Grandjean, quoted by Browning (1965), this level was raised to $96 \mathrm{mg}$. per litre. With the exception of those authors attempting mental testing 
(Grandjean et al., 1955; Bardodej and Vyskocil, 1956), the fixing of limits has largely been based on noting the frequency of complaints, and no one has compared his results with a matching control group. The assessment of exposure measuring unchanged solvent in expired air was considered impractical by Elkins (1954) and Ahlmark and Forssman (195Ib). The odour of trichlorethylene is first detectable at about 60 p.p.m., although this threshold readily rises on continued exposure (Hargarten et al., 196I; Gutch et al., 1965) and although the anaesthetic level is usually thought to be about 10,000 p.p.m., cases of gassing have occurred at lower levels (Longley and Jones, 1963). The exclusion of those with liver, neurological, psychological or cardiovascular disorders from working with trichlorethylene has been suggested (Stüber, I93I ; Hunter, I957). The use of protective clothing to prevent skin damage and nonspecific effects has been recommended (Desoille et al., 1962a; Carrieu, 1927; Schwartz et al., 1957), and patch testing to exclude solvent sensitivity in dermatitis cases occurring in the plastics industry has been described by Malten and Zielhuis (1964). Emergency treatment for gassings follows standard lines, but Lloyd Potter (1958) stressed the avoidance of stimulants containing adrenaline. Bartonicek and Teisinger (1962) suggested specific antidotes which inhibit metabolism, such as disulfiram for severe cases, fructose, or sodium lactate.

\section{REFERENCES}

Adams, E. M., Spencer, H. C., Rowe, V. K., McCollister, D. D., and Irish, D. D. (I95I). Arch. industr. Hyg., 4, 469.

Adriani, J., and Rovenstine, E. A. (1943). Anesthesiology, 4, 253.

Ahlmark, A., and Forssman, S. (1949). Proc. 9th int. Congr. industr. Med., London, 1948, p. 552.

- and - (1951a). Acta physiol. scand., 22, 326. and - (195Ib). Arch. industr. Hyg., 3, 386.

Alford, W. C. (1947). F. industr. Hyg., 29, 396.

American Conference of Governmental Industrial Hygienists (1959). Arch. industr. Hlth, 20, 266.

Andreatch, A. J. (1962). Arch. environm. Hlth, 4, 317.

Ayre, P. (1943). Brit. med. F., 1, 489.

Baader, E. W. (1927). Zbl. Gewerbehyg., 14, 385.

Bardodej, Z., and Vyskocil, J. (1956). Arch. industr. Hlth, 13, 581 .

Barnes, J. M. (1961). Brit. med. F., 2, 1097.

Barrett, H. M. (1936). F. industr. Hyg., 18, 341.

—, Cunningham, J. G., and Jchnston, J. H. (1936). Ibid., $2 \mathrm{r}, 479$.

- and Johnston, J. H. (1939). F. biol. Chem., 127, 765.

Bartonicek, V. (1960). Arch. Gewerbepath. Gewerbehyg., 18, 317.

(1962). Brit. F. industr. Med., 19, 134.

- and Soucek, B. (1959). Arch. Gewerbepath. Gewerbehyg., $17,283$.

- and Teisinger, J. (1962). Brit. F. industr. Med., 19, 216.

Bättig, K., and Grandjean, E. (1963). Arch. environm. Hlth, 7, 694 .
Bell, A. (I95I). N.Z. med.F., 50, I 19.

Bernstine, M. L. (1954). Arch. Surg., 68, 262.

Blumenthal, F. (1924). Dtsch. med. Wschr., 50, 140.

Brain, F. H., and Helliwell, P. J. (1949). Biochem. F., 45, 75.

British Chemical Industry Safety Council (1965). Quart. Safety Summary, 36, 25.

British fournal of Industrial Medicine (1945). Editorial comment, 2, 167.

British Pharmaceutical Codex (1963).

British Pharmacopoeia (1963).

Browning, E. (1943). F. industr. Hyg., 25, 124

- (1952). Toxicity of Industrial Organic Solvents, Med. Res. Coun., Industr. Hlth Res. Bd, Rep. No. 80, p. 169.

- (1959). Brit. F. industr. Med., 16, 23.

- (1965). Toxicity and Metabolism of Industrial Solvents, p. 189. Elsevier, Amsterdam.

Brüning, A., and Schnetka, M. (1933). Arch. Gewerpath. Gewerbehyg., 4, 740.

Buchwald, H. (1965). Trans. Ass. industr. med. Offrs, 15, 100.

Butler, T. C. (1948). F. Pharmacol. exp. Ther., 92, 49.

- (1949a). Ibid., 97, 84.

- (1949b). Ibid., 95, 360.

- (I949c). Fed. Proc., 8, 278.

Calvet, J., Planques, J., Ribet, A., and Coll, J. (1959). Arch. Mal. prof., 20, 297.

Carden, S. (1944). Brit. med. F., 1, 319.

Carpenter, C. P., Smyth, H. F., and Pozzani, U. C. (1949). f. industr. Hyg., 31, 343.

Carrié, P. A., Perrault, M., and Bourdin, J. S. (194I). Arch. Mal. prof., 3, 345.

Carrieu, M. F. (1927). Rev. Hyg. Méd. prev., 49, 348.

- and Marc (1926). Presse méd., 34, I199.

Case, E. H. (1943). Anesthesiology, 4, 523.

Challen, P. J. R., and Hickish, D. E. (1963). Brit. F. industr. Safety, 6, 92.

Chalupa, B., Synkova, J., and Secevik, M. (1960). Brit. f. industr. Med., 17, 238.

Chief Inspector of Factories (1920-1965). Annual Reports.

Clayton, J. I., and Parkhouse, J. (1962). Brit. F. Anaesth., 34, I4I.

Cole, W. H. (1926). F. biol. Chem., 71, 173.

Combey, W. (1965). Publ. Hlth Inspector, 73, 706.

Condon, H. A. (1948). Brit. med. F., 2, 340.

Cotter, L. H. (1950). Arch. industr. Hyg., 1, 319.

Couchman, C. E., and Schulze, W. H. (1939). F. industr. Hyg., 21, 256.

Council on Occupational Health, A.M.A. (1965). Arch. environm. Hlth, 10, 115 .

Culbert, T. D. (1942). Brit. med. f., 2, 679.

Davenport, H. T. (195I). Brit. F. Anaesth., 23, 56.

Dérobert, L. (1944-1945). Arch. Mal. prof., 6, 32 I.

Derrick, E. H., and Johnson, D. W. (1943). Med. F. Aust., 30 (2), 355.

Desoille, H., Pinchon, R. A., Jans, M., and Bourguignon, A. (1962a). Arch. Mal. prof., 23, 693.

,,-- Lille, F., and Bourguignon, A. (1962b). Ibid., 23,5 .

Dodds, G. H. (1945). Brit. med. 7., 1, 769.

Dräger, H., and Dräger, B. (1957). Information on the Drager Gas Detector. Drägerwerk, Lübeck.

Dudley, H. C. (194I). Publ. Hlth Rep. (Wash.), 56, 102 I.

Eichert, H. (1936). F. Amer. med. Ass., 106, 1652.

Elam, J. (1942). Lancet, 2, 309.

Elkins, H. B. (1954). Arch. industr. Hyg., 9, 212. (196r). Arch. environm. Hlth, 2, 45.

- , Hobby, A. K., and Fuller, J. E. (1937). F. industr. Hyg., I9, 474.

and Levine, L. (1939). F. industr. Hyg., 21, 221.

Ellis, M. W., and Bryce Smith, R. (1965). Brit. med. Y., 2, 1412. 
Enderby, G. E. H. (1944). Ibid., 2, 300.

Extra Pharmacopoeia (1958). 24th Edition, the Pharmaceutical Press, London, p. 649.

Fabre, R., and Truhaut, R. (195I). Brit. F. industr. Med., 8, 275.

- and - (1952). Ibid., 9, 39.

Fahy, J. P. (1948). f. industr. Hyg., 30, 205.

Fiessinger, N., and Laur, C. M. (1936). Presse méd., 44, 1797.

- and Loeper, J. (194I). Arch. Mal. prof., 3, 296.

Flinn, F. B. (1946). Amer. F. Med., 1, 388.

Forssman, S., and Ahlmark, A. (1946). Nord. Med., 30, 1033.

-, Gernandt, B., and Goldberg, L. (1948). Acta physiol. scand., 16, 256.

—, and Holmquist, C. E. (1953). Acta pharmacol. (Kbh.), 9, 235.

Foulger, J. H. (1949). F. Amer. med. Ass., 139, 826.

Frant, R., and Westendorf, J. (1950). Arch. industr. Hyg., I, 308.

Friberg, L., Kylin, B., and Nyström, A. (1953). Acta pharmacol. (Kbh.), 9, 303.

Garland, Y. (1942). Brit. med. $\mathcal{f}$., 2, 607.

Génevois, L. (1936). Ann. Hyg. publ. (Paris), 14, 139.

Geiger, A. J. (1943). F. Amer. med. Ass., 123, I4I.

Gerbis, H. (1936). Arch. Gewerbepath. Gewerbehyg., 7, 421.

Giever, P. M., and Cook, W. A. (1960). Arch. environm. Hlth, 21, 233.

Gisclard, J. B. (1960). Ibid., 21, 250.

Glaser, M. A. (I931). F. Amer. med. Ass., 96, 916.

Glynn, L. E., and Himsworth, H. P. (1948). Clin. Sci., 6, 235.

Goldblatt, M. W., and Goldblatt, J. (1956). In Industrial Medicine and Hygiene, vol. 3, Merewether, E. R. A., p. 527. Butterworth, London.

Goldman, F. H., and Seegmiller, C. G. (1943). F. industr. Hyg., 25, 181 .

Gonin, A., and Fraisse, H. (1947). Arch. Mal. prof., 8, 175.

Gordon, R. A., and Shackleton, R. P. W. (1943). Brit. med. f., $\mathbf{1}, 380$.

Grandjean, E. (1960). Arch. environm. Hlth, 1, 106. Münchinger, R., Turrian, V., Haas, P. A., Knoepfel, H. K., and Rosenmund, H. (1955). Brit. F. industr. Med., 12, 131 .

Griffiths, H. F. (1942). Lancet, I, 502.

Gutch, C. F., Tomhave, W. G., and Stevens, S. C. (1965). Ann. intern. Med., 63, 128.

Guyotjeannin, M. C., and van Steenkiste, J. (1958). Arch. Mal. prof., 19, 489.

Habgood, S., and Powell, J. F. (1945). Brit. F. industr. Med., $2,39$.

Hamilton, A., and Johnstone, R. T. (1945). Industrial Toxicology, p. 639. Oxford Univ. Press, New York.

Hargarten, J. J., Hetrick, G. H., and Fleming, A. J. (I96r). Arch. environm. Hlth, 3, 46r.

Harrold, G. C., and Gordon, L. E. (1939). F. industr. Hyg., 21, 491 .

Haworth, J., and Duff, A. (1943). Brit. med. F., r, 381.

Helliwell, P. J., and Hutton, A. M. (1950). Anaesthesia, 5, 4.

Herdman, K. N. (1945). Brit. med. f., 2, 689.

Herzberg, M. (1934). Anesth. Analg. Curr. Res., 13, 203.

Hewer, C. L. (1942). Proc. roy. Soc. Med., 35, 463.

(1943). Ibid., 36, 463 .

- and Belfrage, D. (1938). Lancet, 2, 1290. and Hadfield, C. F. (194r). Brit. med. F., 1, 924.

Hickish, D. E., Smith, J. H., and Bedford, J. (1956). Brit. f. industr. Med., 13, 290.

Hildesheimer, S. (I92 I). Dtsch. med. Wschr., 47, 748.

Hill, C. A. St. (1966). Trans. Soc. occup. Med., 16, 6.

Humphrey, J. H., and McClelland, M. (1944). Brit. med. F., I, 315 .
Hunter, A. R. (1944). Lancet, I, 308.

- (1949). Brit. F. Pharmacol., 4, I77.

- (1964). Neurosurgical Anaesthesia, p. 23. Blackwell, Oxford.

Hunter, D. (1944). Brit. med. F., I, 341.

- (1957). The Diseases of Occupations, 2nd ed., p. 543. English Universities Press.

Imperial Chemical Industries. Non-Inflammable Solvents. Technical Booklet.

Isenschmid, R., and Kunz, E. (1935a). Schweiz. med. Wschr., I6, 530 .

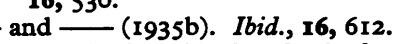

Jackson, D. E. (1934). Anesth. Analg. Curr. Res., 13, 198.

James, W. R. L. (1963). Brit. F. industr. Med., 20, 47.

Joachimoglu, G. (1921). Berl. klin. Wschr., 58, 147.

Johnson, E. E. (1945). Brit. med. f., 2, 33I.

Johnstone, R. T. (194I). Occupational Diseases, p. 452. Saunders.

Jones, G. W., and Scott, G. S. (1943). Anesthesiology, 4, 44I.

Joron, G. E., Cameron, D. G., and Halpenny, G. W. (1955). Canad. med. Ass. F., 73, 890.

Kay, K., Reece, G. M., and Drinker, P. (1939). F. industr. Hyg., 21, 264.

Keenan, R. G. (1960). Arch. industr. Hlth, 21, 261.

Kitigawa, K. (196r). Proc. 13th int. Congr. Occup. Hlth, New York, 1960, p. 506.

Kleinfeld, M., and Tabershaw, I. R. (1954). Arch. industr. Hyg., 10, 134.

Kramer, F. (1921). Berl. klin. Wschr., 58, 149.

Krantz, J. C., Carr, C. J., and Harne, W. G. (1934). Proc. Soc. exp. Biol. (N.Y.), 32, 334.

- - - Musser, R., and Harne, W. G. (1935). F. Pharmacol. exp. Ther., 54, 327.

Kulkarni, R. N. (1944). Indian f. med. Res., 32, 189.

Kylin, B., Reichard, H., Sümegi, I., and Yllner, S. (1962). Nature (Lond.), 193, 395.

Lachnit, V., and Pietschmann, H. (196r). Proc. 13th int. Congr. occup. Hlth, New York, 1960, p. 947.

_ and Rankl, W. (1950). Z. Unfallmed. Berufskr., 43, 334.

Lancet (1944a). Annotation (I), 187.

- (1944b). Annotation (I), 379. (I944C). Annotation (I), 476.

Lande, P., Dervillée, P., and Nun, C. (1939). Arch. Mal. prof., 2, 454 .

Levine, V. E., and Bien, G. E. (1934). Proc. Soc. exp. Biol. (N.Y.), 32, 335.

Lloyd Potter, A. (1958). Handbook of Industrial Hazards, p. 140. Imperial Chemical Industries.

Lloyd-Williams, K. G., and Hewspear, D. (1942). Brit. med. f., 2, 170.

Lob, M. (1960). Med. d. Lavoro, 51, 587.

Longley, E. O., and Jones, R. (1963). Arch. environm. Hlth, $7,249$.

Love, W. S. (I937). Ann. intern. Med., I0, I187.

Malkinson, F. D. (1960). Arch. industr. Hlth., 21, 87.

Mallach, J. F., Marquardt, G. H., and Werch, S. C. (1943). Amer. Hoart F., 26, 377.

Maloof, C. C. (1949). F. industr. Hyg., 31, 295.

Malten, K. E., and Zielhuis, R. L. (1964). Industrial Toxicology and Dermatology in the Production and Processing of Plastics, p. 71. Elsevier, Amsterdam.

Marquardt, G. H., Mallach, J. F., and Werch, S. C. (1943). Proc. Soc. exp. Biol (N.Y.), 52, 2.

Matruchot, D. (1944-1945). Arch. Mal. prof., 6, 396.

McAuley, J. (1943). Brit. med. F., 2, 713.

McBirney, R. S. (1954). Arch. industr. Hyg., ro, 130.

McCollum, J. L. (1930). F. Pharmacol. exp. Ther., 40, 305.

McCord, C. P. (1932). F. Amer. med. Ass., 99, 409.

McLaughlin, R. R. M. (1936). Ibid., 106, 1605. 
Merewether, E. R. A. (1956). Industrial Medicine and Hygiene, vol. 3. Butterworth, London.

Mikiskova, H., and Mikiska, A. (1960). Arch. Gewerbepath. Gewerbehyg., 18, 310.

- and - (1966). Brit. F. industr. Med., 23, I16.

Ministry of Labour. Methods for the Detection of Toxic Substances in Air. Booklet 8. H.M.S.O., London.

- Methods for the Detection of Toxic Substances in Air. Booklet 12. H.M.S.O., London.

-. Safety, Health and Welfare No. 8. H.M.S.O., London. Safety, Health and Welfare No. 15. H.M.S.O., London.

Ministry of National Health and Welfare, Canada (1949). Guide to the Diagnosis of Occupational Diseases. King's Printer, Canada.

Morgan, D. J. (1964). Ann. occup. Hyg., 7, 365.

and Duxbury, G. (1965). Ibid., 8, 253.

Morrison, J. L. (1946). F. Pharmacol. exp. Ther., 86, 336.

Morton, H. J. V. (1943). Brit. med. f., 2, 828.

Naish, N. (1945). Ibid., 2, 367.

O'Connor, W. A. (1954). Ibid., 2, 451.

Oettingen, W. F. von. (1937). F. industr. Hyg., 19, 349.

- (1964). The Halogenated Hydrocarbons of Industrial and Toxicological Importance, p. 240. Elsevier, Amsterdam.

Oljenick, I. (1927). Ned. T. Geneesk., 1, 812.

- (1928). F. Amer. med. Ass., 91, 1085.

Ollivier, H. (1944-1945). Arch. Mal. prof., 6, I59.

Ostlere, G. (1948). Brit. med. F., I, 195.

Pask, E. A. (1942). Proc. roy. Soc. Med., 35, 545.

Patoir, A., Marchand, M., and Ducarne, F. (1943). Arch. Mal. prof., 5, 164 .

Patty, F. A. (1939). F. industr. Hyg., 21, 469.

Paykoc, Z. V., and Powell, J. F. (1945). F. Pharmacol. exp. Ther., 85, 289.

Pernell, C. (1944). F. industr. Hyg., 26, 331.

Plessner, W. (1916a). Berl. klin Wschr., 53, 25.

- (1916b). Ibid., 53, 514.

Powell, J. F. (1945a). Brit. F. industr. Med., 2, 142.

- (1945b). Ibid., 2, 212.

- (1947). Ibid., 4, 233.

Priest, R. J., and Horn, R. C. (1965). Arch. environm. Hlth, II, 361.

Prosser White, R. (1934). The Dermatergoses or Occupational Affections of the Skin, 4th ed., p. 220. Lewis, London.

Riegel, E. R. (1949). Industrial Chemistry. Reinhold, London.

Rivoire, J., Génevois, M., and Tolot, F. (1962). Arch. Mal. prof., 23, 395.

Roche, L., Génevois, M., and Marin, A. (1958). Ibid., 19, 615.

Rogers, G. W., and Kay, K. K. (1947). F. industr. Hyg., 29, 229.

Ross, J. H. (1923)., F. biol. Chem., 58, 641 .
Rubinstein, H. S. (1937). Arch. Neurol. Psychiat. (Chic.), 37, 638.

—, Painter, E., and Harne, O. G. (1939). F. Lab. clin. Med., 24, 1238.

Schwartz, L., and Russell, J. P. (1941). Pub. Hlth Rep. (Wash.), 56, I581.

-, Tulipan, L., and Birmingham, D. J. (1957). Occupational Diseases of the Skin, 3rd ed. Lea and Febiger, Philadelphia.

Seelert (1922). Klin. Wschr., I, 2228.

Seifter, J. (1944). F. industr. Hyg., 26, 250.

Silverman, L. (1943). Ibid., 25, 306.

-, Reece, G. M., and Drinker, P. (1939). Ibid., 21, 270.

Soucek, B., and Vlachovà, D. (1960). Brit. F. industr. Med., 17, 60 .

Spain, D. M. (1965). Arch. environm. Hlth, 11, 364.

Spolyar, L. W., Harger, R. N., Keppler, J. F., and Bumsted, H. E. (1951). Arch. industr. Hyg., 4, 156.

Stentiford, H. B., and Logan, C. J. H. (1956). Lancet, 2, 659

Stephens, J. A. (1945). Brit. med. F., 2, 218.

Striker, C., Goldblatt, S., Warm, I. S., and Jackson, D. E. (1935). Anesth. Analg. Curr. Res., 14, 68.

Stüber, K. (193 I). Arch. Gewerbepath. Gewerbehyg., 2, 398.

Talvitie, N. A. (1958). Arch. industr. Hlth, 17, 563.

Tara, S. (1944-1945). Arch. Mal. prof., 6, 319.

Taylor, H. (1936). f. industr. Hyg., 18, 175

Teare, D. (1948). Brit. med. F., 2, 559.

Tebbens, B. D. (1937). F. industr. Hyg., 19, 204.

Teisinger, J. (196I). Proc. 13th int. Congr. occup. Hlth, New York, I960, p. 987.

Todd, J. (1954). Brit. med. F., I, 439.

Trense, E. (1965). Zbl. Arbeitsmed., 15, 14.

Trott, D. G. (1966). Personal Communication.

Trumper, H. B., Thelwall Jones, A., and Taylor, H. (1936). Lancet, 2, 1390.

Tubich, G. E., Davis, I. H., and Bloomfield, B. D. (I960). Arch. industr. Hlth, $21,424$.

Wagner, F. W. E. (1946). Irish F. med. Sci., 6th ser., p. 717.

Waters, R. M., Orth, O. S., and Gillespie, N. A. (1943). Anesthesiology, 4, I.

Webb, F. J., Kay, K. K., and Nichol, W. E. (1945). F. industr. Hyg., 27, 249.

Weitbrecht, U. (1965). Zbl. Arbeitsmed., 15, 138.

Willcox, W. (1934a). Proc. roy. Soc. Med., 27, 455.

- (1934b). Brit. med. F., 1, 105.

Wirtschafter, Z. T., and Cronyn, M. W. (1964). Arch. environm. Hlth, 9, 180.

Witheridge, W. N., and Walworth, H. T. (1940). F. industr. Hyg., 22, 175.

Woodard, G., Lange, S. W., Nelson, K. W., and Calvery, H. O. (I94I). Ibid., 23, 78.

Wurm, E. (I93I). Arch. Gewerbepath. Gewerbehyg., 2, 767. 